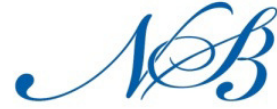

Notulae Scientia Biologicae

Original Article

\title{
Flower Pollinator Interactions within Two Tropical Tree Species of Mizoram, North East India
}

\author{
Kewat Sanjay KUMAR ${ }^{1}$, Vinod Prasad KHANDURI ${ }^{2 *}$
}

\author{
'Mizoram University,Department of Forestry,_Aizawl,Mizoram, India; kewatsanjay@gmail.com \\ ${ }^{2}$ Uttarakhand University of Horticulture and Forestry, College of Forestry, Department of Forestry, Ranichauri Tehri Garhwal - 249 199, Uttarakhand, \\ India;khandurivp@yahoo.com ("correspondingauthor)
}

\begin{abstract}
Understanding the interactions between plants and pollinators is vital in exploring the structural and functional dynamics of tropical forest ecosystem. Such interactions are also helpful in resolving issues of regeneration, maintenance of biodiversity and conservation of tropical forest resources. The aim of this study was to understand the foraging behaviour of floral visitors of two valuable forest species in North East India, viz. Schima wallichii Choisy and Lagerstroemia speciosa (L.) Pers. The types and behaviour of pollinators were assessed by counting of the total number of visits by insects during day time (05:00-18:00) per field visit/flower in the peak flowering season, foraging rate (number of flowers visited/minutes) and average time spent per flower. The frequency of pollinator visits was also determined in terms of visits/flower/hour. Ten species belonging to seven families were recorded visiting $S$. wallichii flowers. The flowers of $L$. speciosa were mainly visited by three species in the family Apidae and one species in the family Calliphoridae. Various moth and bee species were involved in pollination of $S$. wallichii flowers. The Xylcopa spp. of bee showed a high level of functional synchronisation with the floral morphology of L. speciosa.
\end{abstract}

Keywords: anther dehiscence, anthesis, pollination, pollinators, receptivity, tropical

\section{Introduction}

Plant-pollinators interactions are one of the key ecological steps in the reproductive success of plants, particularly in outcrossing species. There has been heightened interest in tropical pollination biology in recent decades due to the phenomenon of global environmental change (Bond, 1994; Murren, 2002). Tropical forest ecosystems are facing accelerated rates of habitat conversion to other land-use systems, leading to loss of biodiversity (Vitousek, 1994). Furthermore, there is a concern regarding the failure of mutualistic interactions (plant-pollinator interaction) due to habitat destruction and fragmentation, which may lead to the cascade extinction of species and loss of valuable biodiversity (Bawa, 1990; Kearns and Inouye, 1997; Renner, 1998). Tropical plant species with disperse and patchy distribution, self-incompatibility, dioecy and high level pollinator specificity are more vulnerable to extinction in case of failed pollination (Bond, 1994; Corlett, 2004). Tropical forest tree species offer a unique opportunity to explore evolutionary tendencies in relation to morphological diversification. Understanding the interactions between plants and pollinators is vital in exploring the structural and functional dynamics of tropical forest ecosystem. Such interactions are also helpful in resolving issues of regeneration, maintenance of biodiversity and conservation of tropical forest resources (Bawa and Headley, 1990; Sharma et al., 2010).

Understanding the diversity and behaviour of floral visitors to different species from a range of ecological characteristics is helpful in evaluating the features of different pollination systems. Key features are: species relationship (Fenster et al., 2004), specific evolutionary tendency between plants and animals (Thompson, 1988; Mitchell et al., 2009) and the structural and functional dynamics of a particular community (Memmott, 1999). Flower anthesis provides a new resource for local floral visitors. Also, local fauna may visit opened flowers for a variety of reasons, such as to feed on nectar or pollen (Bawa, 1990), for shelter (Sakai, 2000) and/or to predate upon other floral visitors. Pollinators are vital in successfully transferring pollen to conspecific individuals at the population level and govern the level of gene flow (House, 1998). Scientific studies are mainly focused on direct observations to record, identify and quantify floral visitors (Momose et al., 1998). For example, even flowers that appear to require specialised pollinators are often visited by a diverse array of faunal visitors (Johnson and Steiner, 2000). Changes in climate are raising concerns about the size of pollinator population and their ecological services (Hegland et al., 2009). Therefore, it is necessary to determine the 
current profile of floral visitors to flowering plants of agricultural and forestry importance (Bronstein 1995; Waser et al., 1996).

Studies of pollinators' diversity of forest genetic resources from the North-East India are lacking. The region also covers biodiversity rich habitat of flora and fauna. The rate and quantity of pollinators' visits to plant species is frequently linked with reproductive success through pollen dispersal (Burd, 1994). Different floral visitors disperse pollen across varying distances, thus affecting pollen flow. Exploring the assemblage of pollinators would be helpful in making conservation and management decisions, as reproduction of animal pollinated plants and their demographic growth is significantly influenced by the reduction in pollinator availability (Kearns et al., 1998). Perturbation in pollinator communities may not only negatively impact seed and fruit set, but also may reduce the adaptive fitness of progeny through changes in the amount and composition of pollen loads (Burd, 1994). Many studies recently revealed that selfing rates are driven by spatial and temporal variation in the composition and abundance of native pollinating animal visitors (Harrison, 2000; Fenster et al., 2001; Christopher et al., 2003; Mitchell et al., 2009). Therefore, it is important to understand the range of pollinator species and their behaviour with regard to valuable forestry trees.

The tropical forest ecosystem of North East India is extremely rich in floral and faunal diversity, but studies on functional aspects of biodiversity are lacking from this region. In general, there is paucity of basic information on the species of pollinators involved in pollination of valuable forest genetic resources. Therefore, the present study was undertaken to map and understand the foraging behaviour of floral visitors of two valuable forest species, Schima wallichii and Lagerstroemia speciosa.

\section{Materials and Methods}

\section{Study site}

The study site was in and around Mizoram University Campus, Tanhril, Aizawl, which is situated about $15 \mathrm{~km}$ West of the state capital Aizawl, just below Tanhril village. The study area lies in between $23^{\circ} 45^{\prime} 25^{\prime \prime}$ and $23^{\circ} 43^{\prime} 37^{\prime \prime} \mathrm{N}$ latitudes and $92^{\circ} 38^{\prime} 39^{\prime \prime}$ and $92^{\circ} 40^{\prime} 23^{\prime \prime}$ E longitudes, with the elevation ranging from $300 \mathrm{~m}$ to $880 \mathrm{~m}$ asl. The area is characterised by a series of undulating slopes with the Western spur fallings under steep slope of the bank of Setlak River. The climate is humid and tropical, characterized by a short winter and long summer with heavy rainfall $(2,100$ $\mathrm{mm})$. The temperature did not fluctuate much throughout the year, and ranged from $12^{\circ} \mathrm{C}$ to $36^{\circ} \mathrm{C}$.

The forest is heterogeneous with 15 species of trees, accounting the majority of individuals over $10 \mathrm{~cm} \mathrm{dbh}$. Density was 160 trees per hectare. The forest is dominated by nine species: Schima wallichii Choisy, Callicarpa arborea Roxb., Anthocephalus cadamba (Roxb.) Miq., Sterculia villosa Roxb., Albizia procera (Roxb.) Benth., Aibizia chinensis (Osbeck) Merrill, Mallotus spp., Sepium spp., Rhus semialata Murray and patchy distributed Gmelina arborea Roxb. and Lagerstroemia speciosa (L.) Pers.
Schima wallichii

Schima is a monotypic, polymorphic genus belonging to the family Theaceae that has a single species, Schima wallichii Choisy. It is an evergreen tree native to warm temperate and tropical regions of Southern and South-Eastern Asia. It is locally used for timber, poles, fuel wood, charcoal making and occasionally as fodder (Tamrakar, 1992). Flowering starts at the age of 5-8 years, depending on growth and site. Seasonal flowering occurs in April-early June with most seeds maturing in January to March next year. The development from flower to fruit thus takes about 9 months. The tree attains a height up to $35 \mathrm{~m}$ with a dense crown and can attain a stem diameter up to $125 \mathrm{~cm}$. Leaves are elliptic-oblong or lanceolate, 6-15 $\times 4-6 \mathrm{~cm}$ in size; flowers are white, $2.5-4 \mathrm{~cm}$ across, scented, axillary solitary or paired. It has a broad distribution occurring from North-Eastern India to Southern China, Thailand, the Malay Peninsula, Sumatra, Java, Borneo and the Philippines, and is adaptive to a wide range of environments (Corlett, 1999; Wu et al., 1999). S. wallichii is a fire resistant, moderately light demanding and often occurs in diverse primary lowland to mountain forests, scrublands and grasslands, but is particularly common in disturbed and secondary forests (Troup, 1921; LiZhen and Li, 1997). Bark contains alkaloids that are used as fish poison and also used for dying ( $\mathrm{Li}-Z$ hen and $\mathrm{Li}, 1997)$. Corollas of the flowers are used to treat uterine disorders and hysteria (Tamrakar, 1992; Siwakoti and Siwakoti, 2000).

\section{Lagerstroemiaspeciosa}

Lagerstroemia speciosa is a large deciduous tree that grows up to $18 \mathrm{~m}$ in height with a diameter of up to $50 \mathrm{~cm}$. Leaves are elliptic-lanceolate. Flowers are mauve coloured in large terminal peduncles up to $25 \mathrm{~cm}$ long. Each flower is $5-8 \mathrm{~cm}$ in diameter with a calyx of 12-15 mm long, tomentose and ribbed with 6 teeth. There are 6-7 petals per flower, each 3-4 cm long (Sinha et al., 2012). Flowers are produced once a year in the height of summer. It is commonly known as Queen's Crape-Myrtle due to its conspicuous beautiful flowers. The species grows naturally in North-Eastern and Southern India, throughout Myanmar, the Philippines and the Chittagong hills of Bangladesh (Troup, 1921). It is a multi-purpose tree species with good quality timber and medicinal values (Suzuki et al., 1999). Seeds are narcotic; the bark and leaves are purgative; the roots are astringent, stimulant and febrifuge (fever removing). A decoction of dried leaves is used in diabetes (Mishra et al., 1990) and anti-obesity (Suzuki et al., 1999).

\section{Floral, pollination and fruit display}

This study was conducted during the flowering seasons (mid April-May for S. wallichii and mid May-June for $L$. speciosa) of the years 2012 and 2013, which covered about one month period for each species in every year. Floral morphometric traits, pollination and fruit formation were observed during the flowering season on ten randomly selected individuals within each population. On each tree, twenty flower buds of similar stage were marked and subsequently observed for anthesis, anther dehiscence and stigma receptivity at 2-h intervals from dawn $(05: 00 \mathrm{~h})$ to dusk $(18: 00 \mathrm{~h})$. Anthesis (the opening of flowers to display its reproductive sexual organs) was observed on the marked flowers on each tree of both study species. Anther dehiscence was assessed at the time of anthesis by using a hand lens $(\times 20)$ to note the time differences between anthesis and 
258

anther dehiscence, and anther dehiscence and stigma receptivity. Receptivity of stigmas was assessed up to 5 days after every 2-h interval during entire day length, by measuring peroxidase activity using the method of Kearns and Inouye (1993). Furthermore, twenty flowers from different trees were harvested to record the flower diameter, sepal and petal length, style, ovary length and ovary circumference, for each species. Similarly, 50 mature fruits from different selected individuals of each species were harvested and the wing length of seeds, seed length (without wing), number of seeds per fruit, number of fruits per inflorescence, length of fruit and circumference of fruit were measured.

\section{Pollinator availability and their frequency}

Ten individuals of each study species (S. wallichii and $L$. speciosa) were chosen arbitrarily within the populations to record the pollinators. Pollinators and their visitation rates were determined on five randomly chosen branches per tree by counting the individuals of insect species visiting to the selected branches per individual tree of each species. Thus, the sample size represented 50 replications $(10 \times 5=50)$ in each study species. Pollinator availability was monitored during peak flowering time (mid April-May for $S$. wallichii and mid May-June for $L$. speciosa). Several inflorescences were observed simultaneously to record the number of encounters of pollinator species interacting with open flowers. Each tree was observed for whole day between 05:00 and 18:00 h in 6-h observation blocks, at every full hour interval between 05:00-06:00, 06:001-07:00, 08:01-09:00 h, etc. The observations were recorded for twenty five days during peak flowering time of both species. The sustainable distribution of each observation block was done in such a manner that all the chosen trees in the population would be monitored in each observation block during the course of the study. The pollinators were assessed in respect of total number of visits by insects during field visit/flower $(\mathrm{n}=10$ trees $\times 5$ branches $\times 10$ flowers per branch $=500$ flowers), foraging rate (number of flowers visited/minutes, $\mathrm{n}=500$ ) and average time ( $(\mathrm{sec})$ spent per flower $(n=500)$. The frequencies of pollinators were also assessed in terms of visits/flower/hour $(\mathrm{n}=500)$.

\section{Results}

The visitation rates differed significantly $(\mathrm{p}<0.0001)$ within the insect species and also varied significantly $(\mathrm{p}<0.001)$ from one year to another. The daily pattern of pollinators' visitation was related to the pattern of anthesis of the flowers of both analyzed species.

In the case of $L$. speciosa, the pattern of anthesis was forenoon (05:00-11:00 hrs) and the peak period of anthesis was recorded between 07:00 and 09:00 hours of the day. The stigma was receptive at the time of anthesis. The anther dehiscence started half an hour after the beginning of receptivity of the stigma. The receptivity continued for 48 hours. The amount of pollen was highest in the morning hours due to high rate of anthesis and anther dehiscence, leading to high visitation rates at that time. Highest quantitative frequency of pollinators was recorded between 07:00 to 09:00 h of the day, which also coincided with the peak timing of anthesis.

For S. wallichii, anthesis in flowers started from $06: 00 \mathrm{~h}$ in the morning and reached to its maximum between 07:00 and 09:00 hours of the day. As the day progressed, the level of anthesis decreased and gone down to its minimum level at 11:00 $\mathrm{h}$; the flower openings were again recorded during afternoon hours between 15:00 and 18:00 h, therefore, the pattern of anthesis was bimodal. Anther dehiscence started one hour after anthesis and followed a diurnal pattern. The receptivity of stigma started after $4 \mathrm{~h}$ of anther dehiscence and remained receptive up to $60 \mathrm{~h}$. The pattern of pollinators visitation, particularly moths, in $S$. wallichii was bimodal, which followed the pattern of anthesis.

Anther dehiscence offers mature pollen grains to the insects, to carry them into the receptive surfaces of stigmas, which in turn, utters the pollination success of a species and play an important part for determining the genetic make-up of populations. The detailed morphometrics of the flowers of both study species are presented in Table 1.

\section{Pollinator visitation in Schima wallichii}

S. wallichii flowers were visited by 10 insect species belonging to Hymenoptera (2 species of bee), Lepidoptera

Table 1. Floral, pollination and seed display of $L$. speciosa and S. wallichii

\begin{tabular}{|c|c|c|}
\hline Floral display & Lagerstroemiaspeciosa & Schima wallichii \\
\hline Sepals & 6, fleshybrownish colour & 5, persistent grey in colour \\
\hline Petals & 6, Pink to pinkish white in color & 5, obovate, creamish white \\
\hline Average length of petals & $5.1 \pm 0.24 \mathrm{~cm}$ & $2.5 \pm 0.04 \mathrm{~cm}$ \\
\hline Average width of petals & $4.8 \pm 0.21 \mathrm{~cm}$ & $2.03 \pm 0.05 \mathrm{~cm}$ \\
\hline Flowerdiameter & $10.5 \pm 0.19 \mathrm{~cm}$ & $3.1 \pm 0.05 \mathrm{~cm}$ \\
\hline Stamen & Yellow, many in number & Yellow, many in numbers, to base of corolla \\
\hline Stigma & Green in colour when receptive & Off white in colour, greenish grey in receptive stage \\
\hline Style length & $2.2 \pm 0.03 \mathrm{~cm}$ & $0.82 \pm 0.012 \mathrm{~cm}$ \\
\hline Ovarylength & $0.6 \pm 0.09 \mathrm{~cm}$ & $0.22 \pm 0.008 \mathrm{~cm}$ \\
\hline Ovarycircumference & $2.4 \pm 0.02 \mathrm{~cm}$ & $0.769 \pm 0.006 \mathrm{~cm}$ \\
\hline \multicolumn{3}{|l|}{ Fruit display } \\
\hline Circumference of fruit & $7.5 \pm 0.02 \mathrm{~cm}$ & $5.32 \pm 0.08 \mathrm{~cm}$ \\
\hline Length of fruit & $3.2 \pm 0.14 \mathrm{~cm}$ & $1.83 \pm 0.03 \mathrm{~cm}$ \\
\hline Number fruits per inflorescence & $25 \pm 1.68$ & \\
\hline Number of seedsper fruit & $145 \pm 4.03$ & $10-30$ \\
\hline Seedlength (without wing) & $0.69 \pm 0.24 \mathrm{~cm}$ & Seedlength: Winged, $0.72 \pm 0.03 \mathrm{~cm}$ \\
\hline Winglength of seeds & $0.91 \pm 0.06 \mathrm{~cm}$ & \\
\hline \multicolumn{3}{|l|}{ Pollination display } \\
\hline Mode of pollination & Entomophilous & Entomophilous \\
\hline Major pollinators & Honeybee and Carpenter bee & HoneybeeandMoths \\
\hline Type of dichogamy & Slightly protandrous (stigma becomes receptive half an hour prior anther dehiscence & Slightly protandrous (stigma becomes receptive after 45 h anther dehiscence \\
\hline Period of stigma receptivity & 48 hours & 60 hours \\
\hline
\end{tabular}


Table 2. Insects visiting the flowers of Schima wallichii in tropical forest site of Mizoram

\begin{tabular}{|c|c|c|c|c|c|}
\hline Order & Family & Scientific name & $\begin{array}{l}\text { Total number of visits by insects } \\
\text { during field visit/flower }(n=500)\end{array}$ & $\begin{array}{l}\text { Foraging rate (No. offlowers } \\
\text { visited } / \mathrm{min})(\mathrm{n}=500)\end{array}$ & $\begin{array}{l}\text { Mean time spent per flower }(\mathrm{sec}) \\
(\mathrm{n}=500)\end{array}$ \\
\hline Hymenoptera & Apidae & Apiscerena & 156 & $1.9 \pm 0.23$ & $22.2 \pm 0.66$ \\
\hline Hymenoptera & Apidae & Xylocopa spp. & 71 & $3.6 \pm 0.49$ & $6.3 \pm 0.32$ \\
\hline Lepidoptera & Lycaenidae & Arhopala eumolphus & 43 & $1.6 \pm 0.22$ & $14.7 \pm 0.57$ \\
\hline Lepidoptera & Hesperiidae & Matapa aria & 33 & $1.5 \pm 0.16$ & $18.3 \pm 0.55$ \\
\hline Lepidoptera & Geometridae & Cabera pusaria & 50 & $1.3 \pm 0.21$ & $11.0 \pm 0.25$ \\
\hline Lepidoptera & Geometridae & Dysphania militaris & 83 & $2.5 \pm 0.34$ & $12.6 \pm 0.61$ \\
\hline Lepidoptera & Zygaenidae & Callamesia midama & 44 & $1.8 \pm 0.24$ & $15.2 \pm 0.57$ \\
\hline Lepidoptera & Zygaenidae & Eterusia aedea & 38 & $1.3 \pm 0.15$ & $21.8 \pm 0.96$ \\
\hline Lepidoptera & Noctuidae & Alypia spp. & 52 & $2.4 \pm 0.16$ & $16.2 \pm 0.53$ \\
\hline Coleoptera & Scarbaeidae & Maladera castanea & 17 & $1.1 \pm 0.09$ & $58.8 \pm 1.23$ \\
\hline
\end{tabular}
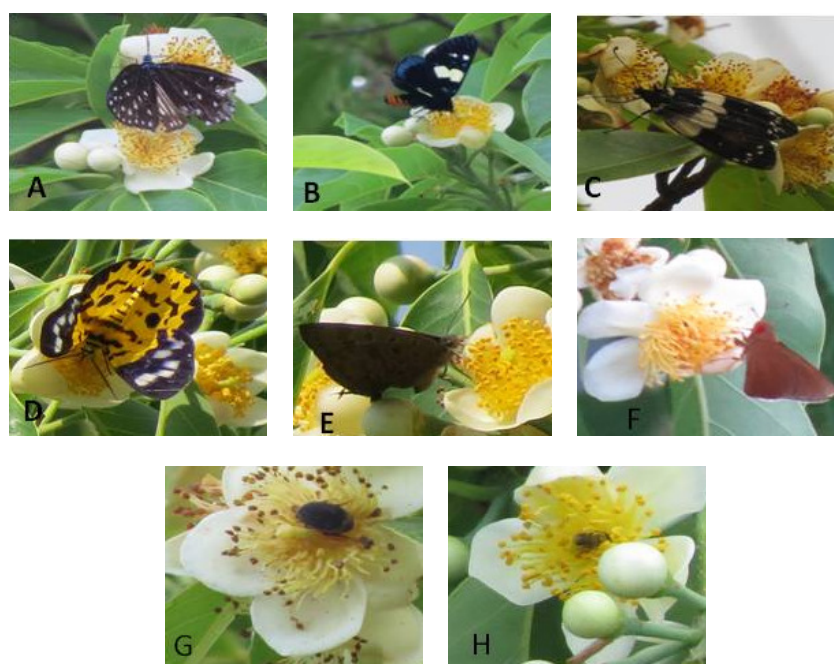

Fig.1. Different pollinators of Schima wallichii; (A) Callamesia midama (Moth); (B) Alypia spp. (Moth); (C) Eterusia aedea (Moth); (D) Dysphania militaris (Moth); (E) Arhopala eumolphus (Butterfly); (F) Matapa aria (Butterfly); (G) Maladera castanea (Bettle); (H) Apis cerena (Indian hive bee)

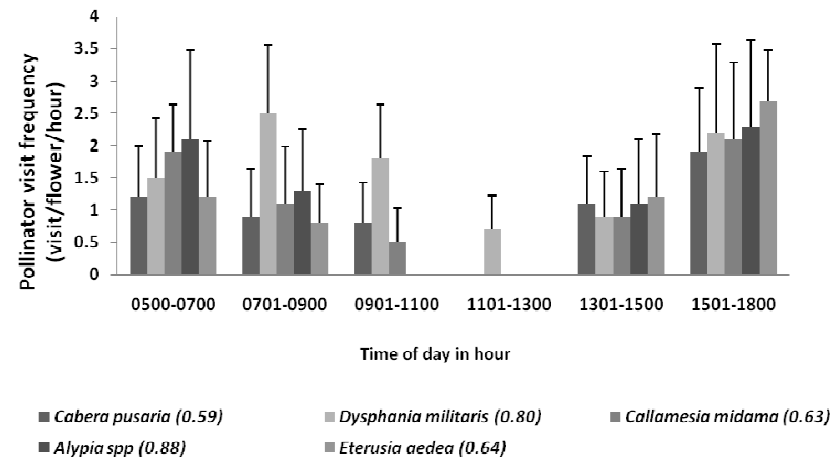

Fig. 3. Frequency of pollinators (moths) visitation in respect to the time of day for S. wallichii in the year 2013 (values in parentheses indicate LSD values for $5 \%$ )

(7 species of moth or butterfly) and Coleoptera ( 1 species of beetle). Foraging abundance is shown in Table 2. All species visited the reproductive parts of flowers (stamen and stigma) (Fig. 1), suggesting all species were effective in pollinating S. wallichii. Moths pollinators (Cabera pusaria, Dysphania militaris, Callemesia midama, Eterusia aedea

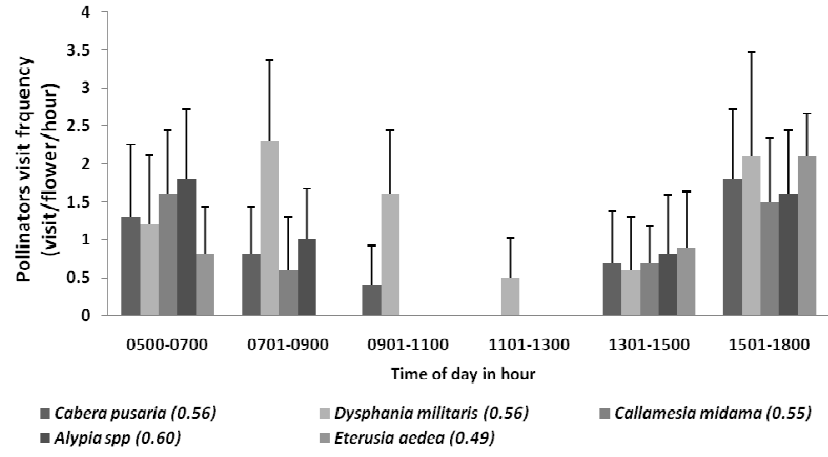

Fig. 2. Frequency of pollinators (moths) visitation in respect to the time of day for $S$. wallichii in the year 2012 (values in parentheses indicate LSD values for $5 \%$ )

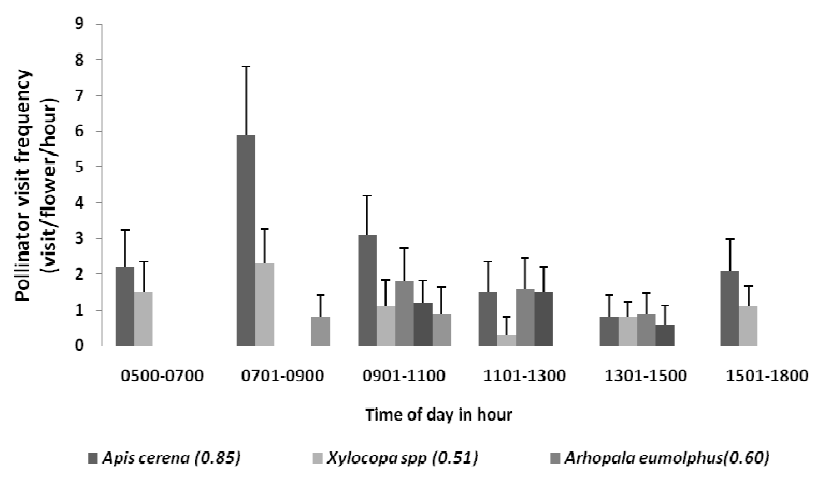

Fig. 4. Frequency of pollinators (bees, butterflies and beetle) visits in respect to the time of day for $S$. wallichii in the year 2012 (values in parentheses indicate LSD values for 5\%)

and Alypia spp.) followed a bimodal pattern (flower were visited more during morning and evening hours) (Figs. 2 and 3), while butterflies (Arhopala eumolphus and Matapa aria) generally visited flowers during 09:00 to 15:00 h of the day. Bees (Apis cerana and Xylocopa spp.) generally visited more often between 07:00 and 11:00 h, but some visited flowers throughout day. The beettle (Maladera castanea) only occasionally visited $S$. wallichii flowers (Figs. 4 and 5), but each visit was much longer than for other species $(58.8 \pm 1.23 \mathrm{sec} /$ flower $)$ compared with the following longest visits such of Apis cerena (22.2 \pm 0.66 $\mathrm{sec} /$ flower), Eterusia aedea (21.8 $\pm 0.96 \mathrm{sec} /$ flower $)$ and 
260

Table 3. Insects visiting the flowers of Lagerstroemia speciosa in tropical forest site of Mizoram

\begin{tabular}{lccccc}
\hline Order & Family & Scientific name & $\begin{array}{c}\text { Total number of visits by insects } \\
\text { duringfield visit/flower }(\mathrm{n}=500)\end{array}$ & $\begin{array}{c}\text { Foragingrate (No. offlowers } \\
\text { visited/min })(\mathrm{n}=500)\end{array}$ & $\begin{array}{c}\text { Mean time spent per flower } \\
(\mathrm{sec})(\mathrm{n}=500)\end{array}$ \\
\hline Hymenoptera & Apidae & Xylocopa spp. & 66 & $4.9 \pm 0.37$ & $5.5 \pm 0.42$ \\
Hymenoptera & Apidae & Apis cerena & 147 & $2.3 \pm 0.21$ & $24.2 \pm 0.78$ \\
Hymenoptera & Apidae & Apisflorea & 115 & $2.6 \pm 0.33$ & $21.3 \pm 0.59$ \\
Diptera & Calliphoridae & Chrysomya megacephala & 88 & $1.3 \pm 0.15$ & $59.7 \pm 1.07$ \\
\hline
\end{tabular}

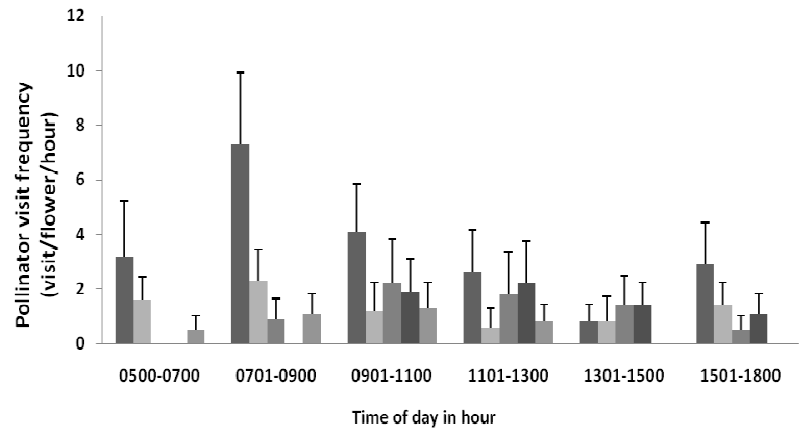

$\square$ Apis cerena (1.33) $\backsim$ Xylocopa spp (0.69) $\backsim$ Arhopala eumolphus (0.88) $\backsim$ Matapa aria $(0.84) \backsim$ Bettle $(0.54$

Fig. 5. Frequency of pollinators (bees, butterflies and beetle) visits in respect to the time of day for $S$. wallichii in the year 2013 (values in parentheses indicate LSD values for 5\%)

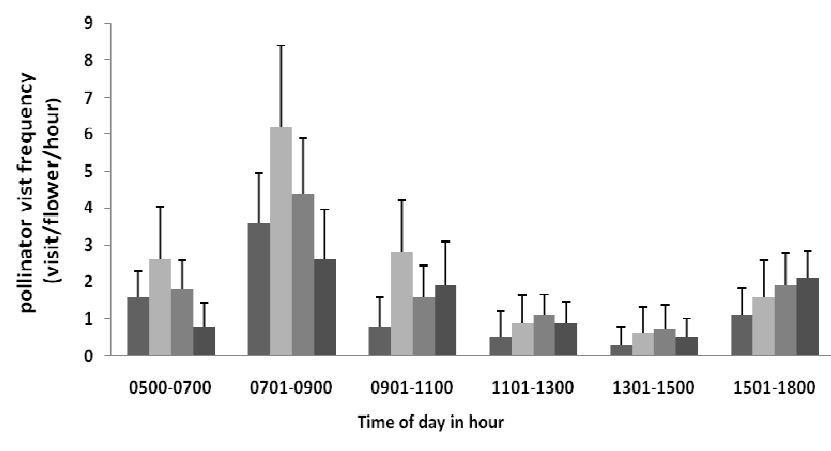

$\square$ Xylocopaspp(0.60) $₫$ Apiscerena(1.0) $₫$ Apisflorea(0.69) $\backsim$ Chrysomya megacephala(0.66)

Fig. 7. Frequency of pollinator visits in respect to the time of day for L. speciosa in the year 2013 (values in parentheses indicate LSD values for $5 \%$ )

Matapa aria $(18.3 \pm 0.55 \mathrm{sec} /$ flower $)$. However, based on foraging rate, e.g. the mean time spent per flower and visitation frequency in different time blocks of the day, Apis cerena, Xylcopa spp. and moths species were considered more effective pollinators than others.

\section{Pollinator visitation in Lagerstroemia speciosa}

The flowers of L. speciosa were observed to be visited by 4 insect species belonging to Hymenoptera (Apis cerena, Apis florea and Xylocopa spp.) and Diptera (Chrysomya megacephala). Insects' visits to $L$. speciosa occurred throughout the day, but the time of maximum visitation frequency was between 07:00 and 09:00 h of day (Figs. 6 and 7). Interestingly, the rate of visitation varied among individuals within the population. There was a definite interaction of floral visitors with the reproductive floral parts of L. speciosa while foraging, as shown in the Fig. 8. On the basis of visitation frequency, foraging rate and average

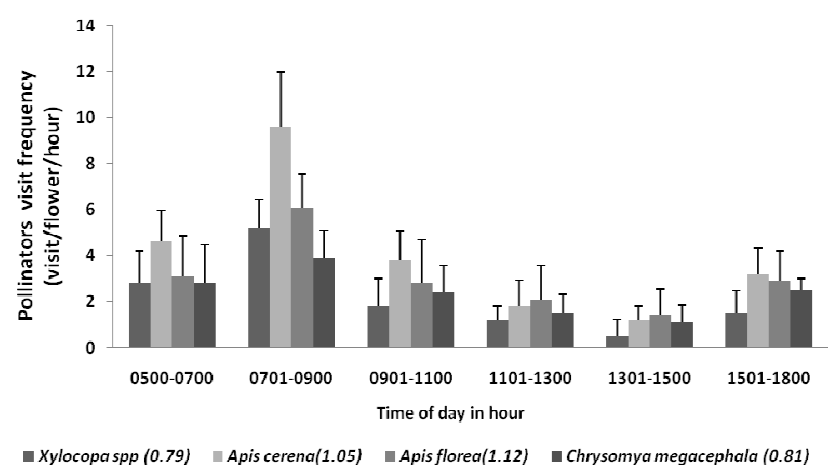

Fig. 6. Frequency of pollinator visits in respect to the time of day for L. speciosa in the year 2012 (values in parentheses indicate LSD values for $5 \%$ )
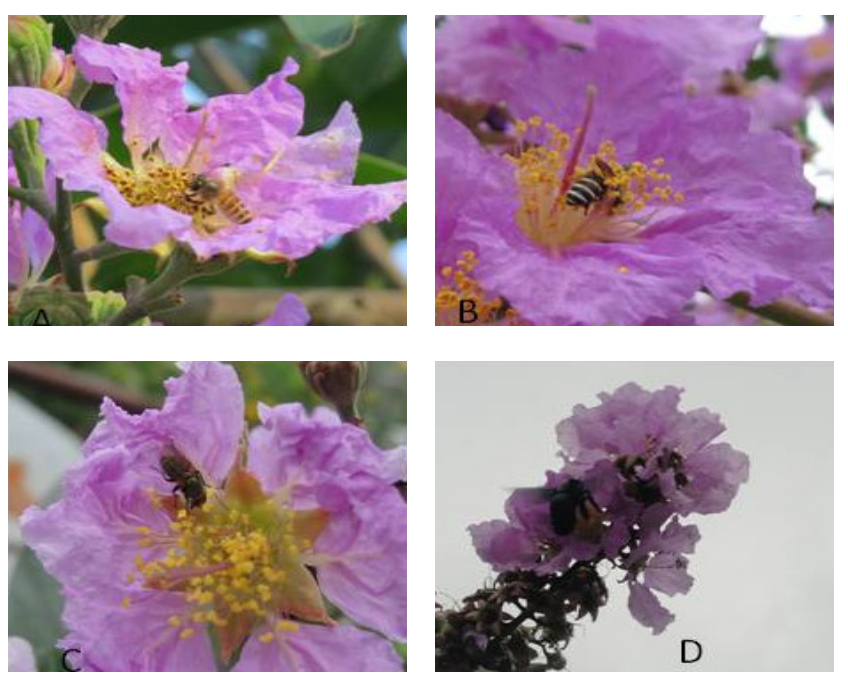

Fig. 8. Pollinators of Lagerstroemia speciosa; (A) Apis cerana (Indian Hive bee); (B) Apis florea (Little bee); (C) Chrysomya megacephala; (D) Xylocopa spp. (Carpenter bee)

time spent per flower, Apis cerena were the most effective pollinators, followed by Xylocopa spp., Apis florea and Chrysomya megacephala.

\section{Discussion}

Both tree study species were visited by members of bee family Apidae, with Xylocopa spp. found to be an important pollinator on the basis of its visitation frequency and rate. Flower size (large for L. speciosa and moderate for $S$. wallichii) along with large number of anthers per flower, copious pollen production (Khanduri et al., 2015) and morphological fitness of Xylocopa bee to the flowers (Khanduri, 2014) were the characteristic features of both 
species to be adapted to pollination by Xylocopa bee. Although $X y l o c o p a$ bees spent less time per flower while foraging than other species, they made frequent inter-flower and inter-tree movements. This characteristic, along with its large size, ability to force into flowers, fast flight, foraging activity during strong winds (Somanathan and Borger, 2001) and long flight range of around $20 \mathrm{~km}$ (Kapil and Dhaliwal, 1969) are the important features for its effectiveness as a pollinator.

Apis cerena visited flowers of both study species with high frequency and thus was another important pollinator. It is one of the most widespread species of canopy pollinator along with Apis dorsata in the rainforests of Western Ghats and Srilanka (Dayanandan et al., 1990; Devy and Davidar, 2003). Apisflorea was also identified as an important floral visitor of $L$. speciosa in the present study, as this species is known to be a key pollinator of field and orchard crops in South-Asia (Batra, 1967; Rehman et al., 1990; Sihag, 2000). However, its role in pollination of wild plants has not been documented previously (Corlett, 2004). Moreover, pollinators, especially bees and moths visitations, were significantly coincided with the pattern of anthesis in both $S$. wallichii and L. speciosa. Chrysomya megacephala, the Diptera belonging to the family Calliphoridae, was a significant floral visitor in terms of dispersed visitation frequency throughout the day and maximum mean time spent per flower in $L$. speciosa. Calliphoridae are regular visitors and important pollinators of Avecenia officinalis (a mangrove species) in South India (Aluri, 1990) and Mangifera indica in sub-tropical India (Bhatia et al., 1995). Calliphoridae are strong fliers and transmit fairly large quantities of pollen (House, 1989; Aluri, 1990), but their function as pollinators in tropical tree species are largely unexplored and underestimated.

Many members of family Lepidoptera have been reported as casual floral visitors and are considered to be less important as pollinators in lowland rainforest compared with the neotropics (Bosch, 1997; Sakai, 2001). In S. wallichii, five species of moths visited flowers irregularly, mainly during early morning and late evening hours. In the Western Ghats region of India, nine tree species have been shown to be pollinated by moths of the family Geometridae (Devy and Davidar, 2003).

\section{Conclusions}

Various moth and bee species were involved in pollination of Schima wallichii flowers. The flowers of S. wallichii showed physical fitness towards functional group of moth and bee in respect to mating success. The Xylcopa spp. of bee showed a high level of functional synchronisation with the floral morphology of $L$. speciosa. The smaller number of species attracted to $L$. speciosa means that the loss of any one or more would have a negative effect on pollination of this species. Tropical forest ecosystems sustain high degree of ecological specialisation of plant-pollinator interactions and have a highly coupled relationship between reproductive phenology and pollinators' availability. Anthropogenic pressure may decouple species interactions during pollination, which may lead to accelerated species extinction. Therefore, studies that combine observation of functional groups of pollinators with examination of pollen-mediated gene flow would greatly improve the understanding of the mechanisms involved in tree pollination.

\section{Acknowledgements}

The authors are grateful to Prof. N. Senthil Kumar and to Mr. David, Department of Biotechnology, Mizoram University, for identifying insect species. V. P. Khanduri is thankful to Council of Scientific and Industrial Research (CSIR), Government of India for financial assistance vide its project no. 38(1186)/08/EMR-II.

\section{References}

Aluri RJ (1990). Observations on the floral biology of certain mangroves. Proceedings of the Indian National Science Academy Part B Biological Sciences 56:367-374.

Balvanera P, Kremen C, Martinez-Ramos M (2005). Applying community structure analysis to ecosystem function: examples from pollination and carbon storage. Ecological Applications 15:360-375.

Batra SWT (1967). Crop pollination and the flower relationships of the wild bees of Ludhiana, India (Hymenoptera: Apoidea). Journal of the Kansas Entomological Society 40:164177.

Bawa KS (1990). Plant-pollinator interactions in tropical rain forests. Annual Review of Ecology and Systematics 21:399-422.

Bhatia R, Gupta D, Chandel JS, Sharma NK (1995). Relative abundance of insect visitors on flowers of major subtropical fruits in Himachal Pradesh and their effect on fruit set. Indian Journal of Agricultural Sciences 65:907-912.

Bond WJ (1994). Do mutualisms matter? Assessing the impact of pollinator and disperser disruption on plant extinction. Philosophical Transactions of the Royal Society of London B Biological Sciences 344:83-90.

Bosch J, Retana J, Cerda X (1997). Flowering phenology, floral traits, and pollinator composition in a herbaceous Mediterranean plant community. Oecologia 109:583-591.

Bronstein SL (1995). The plant-pollinator landscape. In: Hanson L, Fahrig L, Merriam G (Eds). Mosaic landscapes and ecological processes, Chapman and Hall London.

Burd M (1994). Bareman's principle and plant reproduction the role of pollen limitation in fruit and seed set. Botanical Review 60:83-139.

Christopher WD, Gabriela E, Frederic A (2003). Pollen dispersal of tropical trees (Dinizia excelsa: Fabaceae) by native insects and African honeybees in pristine and fragmented Amazonian rainforest. Molecular Ecology 12:753-764.

Corlett RT (1999). Environmental forestry in Hong Kong: 1871-1997. Forest Ecology and Management 116(1-3):93-105.

Corlett RT (2004). Flower visitors and pollination in the Oriental (Indomalayan) Region. Biological Reviews 79:497-532.

Dayanandan S, Attygalla DNC, Abeygunasekera AWWL, Gunatilleke IAUN, Gunatilleke CVS (1990). Phenology and floral morphology in relation to pollination of some Sri Lankan dipterocarps. In: Bawa KS, Hadley M (Eds). Reproductive ecology of tropical forest plants parthenon, Carnforth, UK pp 103-134.

Devy MS, Davidar P (2003). Pollination systems of trees in Kakachi, a mid-elevation wet evergreen forest in Western Ghats, India. American Journal of Botany 90:650-657.

Feinsinger P, Beach JH, Linhart YB, Busby WH, Murray KG (1987). Disturbance, pollinator predictability, and pollination success among Costa Rican cloud forest plants. Ecology 68:12941305. 
262

Fenster CB, Dudash MR (2001). Spatiotemporal variation in the role of hummingbirds as pollinators of Silene virginica (Caryophyllaceae). Ecology 82:844-8451.

Fenster CB, Armbruster WS, Wilson P, Thomson JD, Dudash MR (2004). Pollination syndromes and floral specialization. Annual Review of Ecology, Evolution, and Systematics 35:375-403.

Harrison RD (2000). Repercussions of El Nino: drought causes extinction and the breakdown of mutualism in Borneo. Proceedings of the Royal Society Biological Sciences, Series B, 267:911-915.

Hegland SJ, Nielsen A, Lazaro A, Bjerkens AL, Totland O (2009). How does climate warming affect plant-pollinator interactions? Ecology Letters 12:184-195.

Herrera CM (2005). Plant generalization on pollinators: species property or local phenomenon? American Journal of Botany 92:1320.

House SM (1989). Pollen movement to flowering canopies of pistillate individuals of three rain forest tree species in tropical Australia. Australian Journal of Ecology 14:77-94.

Johnson SD, Steiner KE (2000). Generalization vs. specialization in plant pollination systems. Trends in Ecology and Evolution 15:140143.

Kapil RP, Dhaliwal JS (1969). Biology of Xylocopa species. II. Field activities, flight range and trials on transportation of nests. Journal of Research of Punjab Agricultural University 6:262-271.

Kearns C, Inouye D, Waser N (1998). Endangered mutualism: the conservation of plant-pollinator interactions. Annual Review of Ecology and Systematics 29:83-112.

Kearns CA, Inouye DW (1997). Pollinators, flowering plants, and conservation biology. BioScience 47:297-307.

Khanduri VP, Kumar KS, Sharma CM (2015). Role of pollen production in mating success in some tropical tree species. Brazilian Journal of Botany 38(1):107-112.

Khanduri VP (2014). Annual variation in floral phenology and pollen production in Lagerstroemia speciosa: an entomophilous tropical tree. Songklanakarin Journal of Science and Technology 36(4):389396.

Li-Zhen W, Li ZW (1997). Study on applied effectiveness of biological firebreak network of Schima. Scientia Silvae Sinicae 33(4):338-348.

Memmott J (1999). The structure of a plant-pollinator food web. Ecology Letters 2:276-280.

Mishra Y, Khan MSY, Zafar R, Agarwal SS (1990). Hypoglycaemic activity of leaves of Lagerstroemia speciosa (L.) Pers. Indian Journal of Pharmacology 22:174-176.

Mitchell RJ, Irwin RE, Rebecca J, Flanagan, Karron JD (2009). Ecology and evolution of plant- pollinator interactions. Annals of Botany 103:1355-1363.

Momose K, Yumoto T, Nagamitsu T, Kato M, Nagamasu H, Sakai S, Harrison RD, Itioka T, Hamid AA, Inoue T (1998). Pollination biology in a lowland dipterocarp forest in Sarawak, Malaysia. I. Characteristics of the plant pollinator community in a lowland dipterocarp forest. American Journal of Botany 85:1477-1501.

Murren CJ (2002). Effects of habitat fragmentation on pollination: pollinators, pollinia viability and reproductive success. Journal of Ecology 90:100-107.
Rehman K, Hussain T, Soomro AH, Khuhro RD (1990). Pollinators' activities on mango inflorescence. Proceedings of the Pakistan Congress of Zoology 10:147-152.

Renner SS (1998). Effects of habitat fragmentation on plant pollinator interactions in the tropics. In: Newbery DM, Prins HH, Brown ND (Eds). Dynamics of tropical communities, Blackwell Science, Oxford, UK pp 339-360.

Sahli HF, Conner JK (2006). Characterizing ecological generalization in plant-pollination systems. Oecologia 148:365-372.

Sakai S (2001). A comparison of flowering phenology and pollination systems in the tropical forests of southeast Asia and the Neotropics. In: Ganeshaiah KN, Shaankar RU, Bawa K (Eds). Tropical ecosystems: Structure, diversity and human, Welfare Oxford-IBH, New Delhi, India pp 359-362.

Sharma MV, Umashaanker R, Leather SR, Vasudeva R, Shivanna KR (2010). Floral resources, pollinators and fruiting in threatened tropical deciduous tree. Journal of Plant Ecology 4:259-267.

Sihag RC (2000). Ecobiology of the little honey-bee (Apis florea) in the semi-arid subtropical climates of India. In: Matsuka M, Verma LR, Wongsiri S, Shrestha KK, Partap U (Eds). Asian bees and beekeeping: Progress of research and development. Science Publishers, Enfield, NY, USA pp 46-49.

Sinha GP, Singh DK, Singh KP (2012). Flora of Mizoram, Vol II. Botanical Survey of India, Kolkata.

Siwakoti M, Siwakoti S (2000). Ethnomedicinal uses of plants among the Satar tribe of Nepal. In: MahaehwariJK(Ed). Ethnobotany and medicinal plants of Indian subcontinent, Scientific Publishers, Jodhpur, India pp 79-108.

Somanathan H, Borges RM (2001). Nocturnal pollination by the carpenter bee Xylocopa tenuiscapa (Apidae) and the effect of floral display on fruit set of Heterophragma quadriloculare (Bignoniaceae) in India Biotropica 33:78-89.

Suzuki Y, Unno T, Usshitani M (1999). Antiobesity activity of extracts from Lagerstroemia speciosa L. leaves on female KK-Ay mice. Journal of Nutrition Science Vitaminology 45:791-795.

Tamrakar PR (1992). Management system of natural Schima/Castanopsis forest in the middle hills of Nepal. Banko Jankari 3(2):3-11.

Thompson JN (1988). Co-evolution and alternative hypotheses on insect plant interactions. Ecology 69:893-895.

Troup RS (1920). The silviculture of Indian trees. Vol II. Clarendron Press, Oxford UK.

Troup RS (1921). The silviculture of Indian trees. Vol II. Oxford, Clarendon Press.

Vitousek PM (1994). Beyond global warming: ecology and global change. Ecology 75(7):1861-1876.

Waser NM, Chittka L, Price MV, Williams NM, Ollerton J (1996). Generalization in pollination systems, and why it matters. Ecology 77:1043-1060.

Wu D, Wang Y, Chen Q, Yang J, Jiang M, Wu DS, Wang YR, et al., Jiang MT (1999). A preliminary study of an afforestation trial of Schima superba. Journal of Zhejiang Forestry College 16(2):207210. 